\title{
PEMODELAN JUMLAH KEMATIAN BAYI DI KOTA BANDUNG DENGAN MENGGUNAKAN REGRESI ZERO-INFLATED POISSON
}

\author{
AMALIA DWI PUTRI, DODI DEVIANTO, FERRA YANUAR \\ Program Studi S1 Matematika, \\ Fakultas Matematika dan Ilmu Pengetahuan Alam, Universitas Andalas, \\ Kampus UNAND Limau Manis Padang, Indonesia. \\ email : amaliaputri754@gmail.com,ddevianto@sci.unand.ac.id,ferrayanuar@sci.unand.ac.id
}

Diterima 4 Agustus $2021 \quad$ Direvisi 15 September $2021 \quad$ Dipublikasikan 21 Oktober 2021

\begin{abstract}
Abstrak. Kematian bayi merupakan salah satu indikator dalam menentukan tingkat kesehatan masyarakat. Salah satu upaya untuk mengurangi jumlah kematian bayi adalah dengan mengkaji faktor-faktor penyebabnya. Banyaknya kasus kematian bayi yang berupa data diskrit dan faktor-faktor yang mempengaruhinya dapat dimodelkan menggunakan regresi Poisson. Namun, dalam analisis regresi Poisson sering ditemukan kondisi overdispersi yakni nilai varians dari variabel respon lebih besar dari nilai mean. Overdispersi dapat terjadi karena terlalu banyaknya nilai nol (excess zeros) pada variabel respon. Model regresi Zero-Inflated Poisson merupakan salah satu metode yang dapat mengatasi masalah overdispersi. Pada penelitian ini, data kasus jumlah kematian bayi memiliki terlalu banyak nilai nol, sehingga regresi Zero-Inflated Poisson lebih tepat digunakan untuk memodelkan jumlah kematian bayi dan faktor-faktor yang mempengaruhinya di Kota Bandung Tahun 2019. Hasil analisis menunjukkan bahwa faktor-faktor yang berpengaruh secara signifikan terhadap kasus jumlah kematian bayi adalah persentase berat badan bayi lahir rendah (BBLR), persentase kunjungan neonatal selama $3 \times$ dan persentase bayi yang diberikan ASI eksklusif.
\end{abstract}

Kata Kunci: Excess Zeros, Overdispersi, Regresi Poisson, Regresi Zero-Inflated Poisson

\section{Pendahuluan}

Mortalitas atau kematian merupakan salah satu dari tiga komponen demografi yang dapat mempengaruhi jumlah dan komposisi umur penduduk. Salah satu mortalitas yang dikenal yaitu kematian bayi (infant mortality). Kematian bayi dapat didefinisikan sebagai kematian yang terjadi pada bayi dengan usia kurang dari 1 tahun. Kematian bayi dapat diwakili oleh angka kematian bayi, dimana angka kematian bayi merupakan jumlah kematian bayi di bawah usia 1 tahun pada tahun tersebut per 1000 kelahiran.

${ }^{*}$ penulis korespondensi 
Banyaknya kejadian kecelakaan dalam jangka waktu tertentu di suatu tempat ataupun banyaknya kematian dalam daerah tertentu akibat wabah penyakit merupakan contoh kejadian Poisson [2]. Dalam melakukan analisis regresi Poisson, nilai mean dan nilai varians dari variabel respon harus sama. Namun, terkadang nilai varians dari variabel respon lebih besar dari nilai mean atau kondisi tersebut dinamakan dengan overdispersi. Salah satu regresi yang dapat digunakan untuk mengatasi masalah tersebut yaitu dengan menggunakan regresi Zero-Inflated Poisson.

Model regresi Zero-Inflated Poisson telah dikembangkan oleh beberapa peneliti, yang bisa dilihat lebih detail pada [3], [5], [7] dan [8]. Dalam [8] juga dibahas tentang regresi Zero-Inflated Poisson pada kasus faktor-faktor yang mempengaruhi banyaknya klaim asuransi kendaraan bermotor. Pada penelitian ini, data jumlah kematian bayi di Kota Bandung yang diperoleh dari Profil Kesehatan Kota Bandung Tahun 2019 memiliki terlalu banyak nilai nol (excess zeros). Oleh sebab itu, pada penelitian ini peneliti menggunakan regresi Zero-Inflated Poisson dalam menentukan model yang dapat menggambarkan jumlah kematian bayi di Kota Bandung.

\section{Landasan Teori}

\subsection{Regresi Poisson}

Regresi Poisson merupakan salah satu penerapan dari Generalized Linier Model (GLM) dimana GLM adalah sebuah pengembangan dari model linier klasik yang mengasumsikan variabel responnya berdistribusi normal. Terdapat tiga komponen dalam Generalized Linear Model (GLM) yaitu Random Component, Systematic Component, dan Link Function [9]. Regresi Poisson termasuk kedalam komponen Link Function pada Generalized Linear Model (GLM) dan merupakan salah satu bentuk regresi yang menggambarkan hubungan antara variabel respon $(Y)$ yang berupa data diskrit atau data cacahan (count data) dengan variabel prediktor $(X)$ yang berupa data diskrit, kontinu, kategorik atau campuran [7]. Misalkan $Y$ suatu peubah acak yang berdistribusi Poisson $(Y \sim P O I(\mu))$, maka fungsi kepekatan peluang dari $Y$ dapat ditulis sebagai berikut:[1]

$$
f(y ; \mu)=\frac{\left(e^{-\mu}\right)\left(\mu^{y}\right)}{y !} ; y=0,1,2, \cdots
$$

dengan nilai harapan dan ragam yaitu $E(Y)=\mu=\operatorname{Var}(Y)$

Dengan menggunakan fungsi link, model regresi Poisson dapat dituliskan dalam bentuk sebagai berikut:

$$
g\left(\mu_{i}\right)=\ln \left(\mu_{i}\right)=x_{i}^{T} \beta=\beta_{0}+\beta_{1} x_{i 1}+\beta_{2} x_{i 2}+\cdots+\beta_{p} x_{i p}
$$

atau

$$
\mu_{i}=\exp \left(x_{i}^{T} \beta\right)=\exp \left(\beta_{0}+\beta_{1} x_{i 1}+\beta_{2} x_{i 2}+\cdots+\beta_{p} x_{i p}\right)
$$

\subsection{Multikolinearitas}

Multikolinearitas bertujuan untuk melihat terdapatnya hubungan multikolinearitas antar masing-masing variabel prediktor dalam model persamaan regresi. Salah satu 
cara untuk mendeteksi adanya multikolinieritas dalam model regresi dapat dilihat dari nilai Variance Inflation Factor (VIF). Jika nilai VIF dari masing-masing variabel prediktor lebih besar dari 10, maka hal tersebut menunjukkan adanya masalah multikolinearitas yang kuat pada variabel tersebut. Nilai VIF dapat ditulis sebagai berikut:

$$
V I F_{j}=\frac{1}{1-R_{j}^{2}}, j=1,2, \cdots, p
$$

dengan $R_{j}^{2}$ adalah koefisien determinasi yang diperoleh dari meregresikan antara variabel prediktor ke-j dengan variabel prediktor lainnya.

\subsection{Overdispersi}

Model regresi Poisson mensyaratkan adanya asumsi yang mendasari dalam melakukan analisis regresi Poisson yaitu pada variabel respon harus terjadi equidispersi (nilai mean dan varians dari variabel respon bernilai sama). Namun, dalam analisisnya terkadang terjadi permasalahan overdispersi pada data yang dimodelkan dengan distribusi Poisson. Overdispersi dapat terjadi karena banyaknya jumlah pengamatan yang bernilai nol pada variabel respon. Overdispersi adalah kondisi pada saat nilai varians lebih besar dari nilai mean $(\operatorname{Var}(Y)>E(Y))$. Overdispersi dapat dilihat dari taksiran dispersi yaitu nilai Deviance dan Pearson Chi-square dibagi dengan derajat bebasnya bernilai lebih besar dari satu [3].

\subsection{Zero-Inflated Poisson Regression}

Salah satu metode yang dapat digunakan untuk mengatasi masalah overdispersi yaitu dengan menggunakan regresi Zero-Inflated Poisson. Berikut fungsi kepekatan peluang untuk regresi Zero-Inflated Poisson: [8]

$$
P\left(Y_{i}=y_{i}\right)=\left\{\begin{array}{l}
\omega_{i}+\left(1-\omega_{i}\right) e^{-\mu_{i}}, \text { untuk } y_{i}=0 \\
\left(1-\omega_{i}\right) \frac{e^{-\mu_{i}} \mu_{i}^{y_{i}}}{y_{i} !}, \text { untuk } y_{i}>0,0 \leq \omega_{i} \leq 1
\end{array}\right.
$$

Dari fungsi peluang peubah acak yang memiliki distribusi ZIP tersebut, maka diperoleh nilai harapan dan varians sebagai berikut:

$$
\begin{aligned}
E\left(Y_{i}\right) & =\left(1-\omega_{i}\right) \mu_{i} \\
\operatorname{Var}\left(Y_{i}\right) & =\mu_{i}\left(1-\omega_{i}\right)\left(1+\mu_{i} \omega_{i}\right)
\end{aligned}
$$

Model hubungan untuk regresi Zero-Inflated Poisson yaitu: [8]

$$
\begin{gathered}
\ln (\mu)=X \beta \\
\operatorname{logit}(\omega)=\log \left(\frac{\omega}{1-\omega}\right)=X \gamma
\end{gathered}
$$




\subsection{Pengujian Kesesuaian Model}

Pengujian kesesuaian model dilakukan untuk melihat apakah model yang diperoleh sudah layak atau sesuai menjelaskan data atau tidak.

(1) Regresi Poisson.

Hipotesis pengujian kesesuian untuk model regresi Poisson yaitu: [8]

$$
\begin{aligned}
& H_{0}: \beta_{1}=\beta_{2}=\cdots=\beta_{p}=0, \\
& H_{1}: \text { paling sedikit ada satu } \beta_{j} \neq 0, \text { dengan } j=1,2, \cdots, p,
\end{aligned}
$$

dengan statistik uji rasio likelihood adalah sebagai berikut:

$$
G=-2 \ln \left[\frac{L_{0}}{L_{1}}\right]
$$

Kriteria uji atau aturan keputusannya adalah tolak $H_{0}$ pada taraf signifikansi $\alpha$ jika $G>\chi_{\alpha(p)}^{2}$.

(2) Regresi Zero-Inflated Poisson.

Hipotesis pengujian kesesuaian untuk model regresi Zero-Inflated Poisson yaitu:

$H_{0}: \beta_{1}=\beta_{2}=\cdots=\beta_{p}=\gamma_{1}=\gamma_{2}=\cdots=\gamma_{p}=0$,

$H_{1}$ : paling sedikit ada satu $\beta_{j} \neq 0$, atau $\gamma_{j} \neq 0$, dengan $j=1,2, \cdots, p$.

Statistik uji yang digunakan yaitu statistik uji rasio likelihood dengan rumus sebagai berikut:

$$
G=2 \ln \left[\frac{L(y ; \hat{\omega})}{L(y ; \hat{\Omega})}\right]
$$

Kriteria uji atau aturan keputusannya adalah tolak $H_{0}$ pada taraf signifikansi $\alpha$ jika $G>\chi_{\alpha(p)}^{2}$.

\subsection{Pengujian Signifikansi Parameter}

Pengujian signifikansi parameter model dilakukan untuk mengetahui pengaruh yang dihasilkan oleh variabel prediktor terhadap variabel respon secara individual.

(1) Regresi Poisson.

Hipotesis uji signifikansi parameter untuk model regresi Poisson, yaitu: [8]

$$
\begin{aligned}
& H_{0}: \beta_{j}=0, \\
& H_{1}: \beta_{j} \neq 0, \text { untuk suatu } j=1,2, \cdots, p,
\end{aligned}
$$

dengan statistik uji Wald sebagai berikut:

$$
W_{j}=\left(\frac{\hat{\beta}_{j}}{S E\left(\hat{\beta}_{j}\right)}\right)^{2}
$$

Kriteria uji atau aturan keputusan pengujian ini adalah tolak $H_{0}$ pada taraf signifikansi $\alpha$ jika $W_{j}>\chi_{\alpha(1)}^{2}$.

(2) Regresi Zero-Inflated Poisson 
(a) Uji signifikansi parameter model $\ln (\mu)=X \beta[5]$

Hipotesis uji:

$$
\begin{aligned}
& H_{0}: \beta_{j}=0, \\
& H_{1}: \beta_{j} \neq 0, \text { untuk suatu } j=1,2, \cdots, p,
\end{aligned}
$$

Statistik uji Wald yang digunakan adalah sebagai berikut:

$$
W_{j}=\left(\frac{\hat{\beta}_{j}}{S E\left(\hat{\beta}_{j}\right)}\right)^{2}
$$

Jika nilai $W_{j}>\chi_{\alpha(1)}^{2}$ maka aturan keputusannya yaitu tolak $H_{0}$ pada taraf signifikansi $\alpha$.

(b) Uji signifikansi parameter model $\operatorname{logit}(\omega)=X \gamma[5]$

Hipotesis uji:

$$
\begin{aligned}
& H_{0}: \gamma_{j}=0, \\
& H_{1}: \gamma_{j} \neq 0, \text { untuk suatu } j=1,2, \cdots, p,
\end{aligned}
$$

Statistik uji Wald yang digunakan adalah sebagai berikut:

$$
W_{j}=\left(\frac{\hat{\gamma}_{j}}{S E\left(\hat{\gamma}_{j}\right)}\right)^{2}
$$

Jika nilai $W_{j}>\chi_{\alpha(1)}^{2}$ maka aturan keputusannya yaitu tolak $H_{0}$ pada taraf signifikansi $\alpha$.

\section{Metodologi Penelitian}

Data yang digunakan dalam penelitian ini adalah data sekunder yang diperoleh dari Profil Kesehatan Kota Bandung Tahun 2019 yang bersumber dari Dinas Kesehatan Kota Bandung Tahun 2019.[4] Penelitian ini terdiri dari variabel respon ( $Y$ ) yaitu jumlah kematian bayi di Kota Bandung, dan variabel prediktor $(X)$ yaitu persentase berat badan bayi lahir rendah / BBLR $\left(X_{1}\right)$, jumlah penanganan komplikasi kebidanan $\left(X_{2}\right)$, persentase kunjungan neonatal selama $3 \times\left(X_{3}\right)$, jumlah tenaga kesehatan di setiap puskesmas Kota Bandung $\left(X_{4}\right)$, persentase bayi mendapat vitamin $\mathrm{A}\left(X_{5}\right)$, persentase bayi yang diberikan ASI eksklusif $\left(X_{6}\right)$, dan persentase keluarga dengan akses sanitasi yang layak $\left(X_{7}\right)$.

\section{Analisis dan Pembahasan}

\subsection{Analisis Deskriptif Data}

Pada Tabel 1 diberikan hasil analisis deskriptif variabel respon yaitu jumlah kematian bayi di Kota Bandung Tahun 2019.

Berdasarkan hasil analisis deskriptif variabel pada Tabel 1 dapat dilihat bahwa rata-rata jumlah kematian bayi di Kota Bandung Tahun 2019 adalah 0,375 dengan jumlah kasus kematian bayi terbanyak di setiap puskesmas yaitu sebanyak 5 kasus kematian. Variabel respon $(Y)$ memiliki nilai rata-rata yang jauh berbeda dari nilai maksimumnya. Selanjutnya, rata-rata persentase $\operatorname{BBLR}\left(X_{1}\right)$ di Kota 
Tabel 1. Statistika Deskriptif Variabel

\begin{tabular}{|c|c|c|c|c|}
\hline Variabel & Minimum & Maksimum & Mean & Varians \\
\hline$Y$ & 0 & 5,00 & 0,375 & 0,718 \\
\hline$X_{1}$ & 0,00 & 13,21 & 1,9894 & 5,605 \\
\hline$X_{2}$ & 0,00 & 325 & 77,65 & 4197,116 \\
\hline$X_{3}$ & 70,32 & 100,00 & 94,96 & 48,685 \\
\hline$X_{4}$ & 6 & 37 & 14,97 & 49,696 \\
\hline$X_{5}$ & 0,00 & 100,00 & 92,93 & 292,679 \\
\hline$X_{6}$ & 25,00 & 100,00 & 66,82 & 350,596 \\
\hline$X_{7}$ & 6,48 & 100,00 & 66,62 & 656,505 \\
\hline
\end{tabular}

Bandung sebanyak 1,9894 dengan persentase BBLR tertinggi yaitu 13,21\%. Ratarata jumlah penanganan komplikasi kebidanan $\left(X_{2}\right)$ sebanyak 77,65 dengan jumlah penanganan tertinggi sebanyak 325 penanganan. Rata-rata persentase kunjungan neonatal selama $3 \mathrm{x}\left(X_{3}\right)$ di Kota Bandung sebanyak 94,96 dengan persentase kunjungan neonatal tertinggi yaitu 100\%. Rata-rata jumlah tenaga kesehatan setiap puskesmas $\left(X_{4}\right)$ di Kota Bandung sebanyak 14,97 dengan jumlah tenaga kesehatan paling banyak yaitu 37 orang. Rata-rata persentase bayi mendapat vitamin A $\left(X_{5}\right)$ di Kota Bandung sebanyak 92,93 dengan persentase bayi mendapat vitamin A tertinggi sebanyak $100 \%$. Rata-rata persentase bayi yang diberikan ASI eksklusif $\left(X_{6}\right)$ sebanyak 66,82 dengan persentase pemberian ASI ekslusif tertinggi yaitu $100 \%$. Rata-rata persentase penduduk dengan akses sanitasi yang layak $\left(X_{7}\right)$ di Kota Bandung sebanyak 66,62 dengan persentase tertinggi yaitu $100 \%$.

\subsection{Pengujian Distribusi Poisson pada Data Variabel Respon}

Pengujian distribusi Poisson dengan menggunakan uji Kolmogorov-Smirnov. Uji Kolmogorov-Smirnov adalah suatu uji kebaikan model yang menguji tingkat kesesuaian antara distribusi serangkaian nilai sampel (skor yang diobservasi) dengan suatu distribusi teoritis tertentu [6]. Hasil dari pengujian distribusi Poisson dapat dilihat pada Tabel 2.

Tabel 2. Hasil Pengujian Distribusi Poisson

\begin{tabular}{|c|c|c|}
\hline $\mathbf{n}$ & Nilai Asymp Sig. & Nilai $D_{\text {hitung }}$ \\
\hline 80 & 0,570 & 0,088 \\
\hline
\end{tabular}

Berdasarkan hasil pengujian diperoleh nilai $D_{\text {hitung }}=0,088$ dan nilai Asymp Sig. (2-tailed) $=0,570$. Nilai $D_{\text {tabel }}$ untuk taraf uji $\alpha=5 \%$ dan $\mathrm{n}=80$ yaitu $D_{(80 ; 0,05)}=0,150$. Nilai $D_{\text {hitung }}<D_{\text {tabel }}$ dan nilai Asymp Sig. (2-tailed) $>\alpha$, maka diputuskan untuk tidak tolak $H_{0}$ sehingga dapat disimpulkan bahwa data variabel respon mengikuti distribusi Poisson. 


\subsection{Pengujian Multikolinearitas}

Pada Tabel 3 diberikan nilai Variance Inflation Factor(VIF) dari masing-masing variabel prediktor.

Tabel 3. Nilai VIF masing-masing variabel prediktor

\begin{tabular}{|c|c|}
\hline Variabel Prediktor & VIF \\
\hline Persentase berat badan bayi lahir rendah (BBLR) $\left(X_{1}\right)$ & 1,1266 \\
\hline Jumlah penanganan kompilasi kebidanan $\left(X_{2}\right)$ & 1,6876 \\
\hline Persentase kunjungan neonatal selama 3x $\left(X_{3}\right)$ & 1,1008 \\
\hline Jumlah tenaga kesehatan di setiap puskesmas Kota Bandung $\left(X_{4}\right)$ & 1,5816 \\
\hline Persentase bayi mendapat vitamin A $\left(X_{5}\right)$ & 1,0374 \\
\hline Persentase bayi yang diberikan ASI eksklusif $\left(X_{6}\right)$ & 1,0670 \\
\hline Persentase penduduk dengan akses sanitasi yang layak $\left(X_{7}\right)$ & 1,1048 \\
\hline
\end{tabular}

Berdasarkan Tabel 3 dapat dilihat bahwa nilai VIF dari masing-masing variabel prediktor tidak lebih dari 10 . Hal ini menunjukkan tidak terdapat multikolinearitas pada variabel prediktor yang artinya antar variabel prediktor dengan variabel prediktor lainnya tidak saling berkolerasi, sehingga semua variabel prediktor layak diikutsertakan dalam pembentukan model regresi.

\subsection{Model Regresi Poisson}

Berikut ini disajikan Tabel 4 yang menunjukkan hasil analisis regresi Poisson:

Tabel 4. Hasil analisis regresi Poisson

\begin{tabular}{|c|c|c|c|c|}
\hline Variabel & Parameter & Estimasi & $\boldsymbol{S E}$ & $\boldsymbol{p}$-value \\
\hline Intersep & $\beta_{0}$ & $-11,6933$ & 5,5858 & 0,0363 \\
\hline$X_{1}$ & $\beta_{1}$ & 0,0615 & 0,0561 & 0,2728 \\
\hline$X_{2}$ & $\beta_{2}$ & 0,0025 & 0,0037 & 0,5043 \\
\hline$X_{3}$ & $\beta_{3}$ & $-0,0168$ & 0,0280 & 0,5500 \\
\hline$X_{4}$ & $\beta_{4}$ & 0,0231 & 0,0294 & 0,4316 \\
\hline$X_{5}$ & $\beta_{5}$ & 0,1106 & 0,0564 & 0,0497 \\
\hline$X_{6}$ & $\beta_{6}$ & 0,0206 & 0,0112 & 0,0656 \\
\hline$X_{7}$ & $\beta_{7}$ & $-0,0105$ & 0,0077 & 0,1712 \\
\hline
\end{tabular}

Langkah selanjutnya adalah melakukan pengujian kesesuaian model regresi Poisson untuk mengetahui apakah model regresi Poisson sudah sesuai menjelaskan data atau tidak. Pada pengujian kesesuaian model regresi Poisson diperoleh nilai $\mathrm{G}$ sebesar 21,64. Kriteria pengujian ini menggunakan taraf signifikansi $\alpha=5 \%$ dengan derajat bebas 7 , sehingga diperoleh $\mathrm{G}=21,64>\chi_{0,05(7)}^{2}=$ 14,0671. Aturan keputusan yang diperoleh yaitu tolak $H_{0}$ pada taraf signifikansi $5 \%$, artinya model regresi Poisson sudah sesuai dan dapat digunakan untuk melihat hubungan antara variabel respon dengan variabel prediktornya. Selanjutnya, akan 
dilakukan pengujian signifikansi parameter yang mana hasilnya dapat dilihat pada Tabel 5 berikut.

Tabel 5. Pengujian signifikansi parameter regresi Poisson

\begin{tabular}{|c|c|c|c|}
\hline Parameter & $W_{j}$ & $\chi_{0,05(1)}^{2}$ & Keterangan \\
\hline$\beta_{1}$ & 1,20178 & 3,841 & Tidak Tolak $H_{0}$ \\
\hline$\beta_{2}$ & 0,45654 & 3,841 & Tidak Tolak $H_{0}$ \\
\hline$\beta_{3}$ & 0,36 & 3,841 & Tidak Tolak $H_{0}$ \\
\hline$\beta_{4}$ & 0,61735 & 3,841 & Tidak Tolak $H_{0}$ \\
\hline$\beta_{5}$ & 3,84549 & 3,841 & Tolak $H_{0}$ \\
\hline$\beta_{6}$ & 3,38297 & 3,841 & Tidak Tolak $H_{0}$ \\
\hline$\beta_{7}$ & 1,85950 & 3,841 & Tidak Tolak $H_{0}$ \\
\hline
\end{tabular}

Dari hasil pengujian signifikansi masing-masing parameter untuk model regresi Poisson diperoleh bahwa parameter $\beta_{5}$ signifikan, artinya pada taraf signifikansi $5 \%$ variabel prediktor $X_{5}$ (persentase bayi mendapat vitamin A) memiliki kontribusi terhadap variabel respon $Y$. Variabel prediktor yang tidak berpengaruh terhadap variabel respon dapat dikeluarkan dari model, sehingga akan dilakukan pendugaan model regresi Poisson kembali tetapi hanya melibatkan variabel yang signifikan saja. Hasil analisis regresi Poisson yang hanya melibatkan variabel $X_{5}$ dapat dilihat pada Tabel 6 berikut.

Tabel 6. Hasil analisis regresi Poisson dengan parameter yang signifikan

\begin{tabular}{|c|c|c|c|c|}
\hline Variabel & Parameter & Estimasi & $\exp (\beta)$ & Standar Error \\
\hline Intersep & $\beta_{0}$ & $-9,5465$ & 0,0000715 & 4,84310 \\
\hline$X_{5}$ & $\beta_{5}$ & 0,0883 & 1,092316 & 0,04919 \\
\hline
\end{tabular}

Jadi, diperoleh model regresi Poisson untuk paramater yang signifikan yaitu:

$$
\mu_{i}=\exp \left(-9,5465+0,0883 X_{5 i}\right) \text {. }
$$

\subsection{Pengujian Overdispersi}

Overdispersi adalah kondisi pada saat nilai varians lebih besar dari nilai mean $(\operatorname{Var}(Y)>E(Y))$. Berdasarkan Tabel 1 dapat dilihat bahwa nilai mean dari variabel respon $(Y)$ adalah 0,38 dan nilai varians dari variabel respon $(Y)$ adalah 0,718. Nilai varians lebih besar dari nilai mean maka dapat disimpulkan bahwa variabel respon mengalami kondisi overdispersi. Berikut hasil uji overdispersi berdasarkan nilai Pearson Chi-Square dan nilai Deviance.

Dari Tabel 5 diperoleh bahwa nilai Deviance dan nilai Pearson Chi-Square yang dibagi derajat bebasnya bernilai lebih besar dari 1 sehingga variabel respon mengalami kondisi overdispersi. Overdispersi juga dapat dilihat dari nilai dispersi yang diperoleh sebesar 1,295619. Nilai dispersi tersebut lebih besar dari 1 yang artinya 
Tabel 7. Uji Overdispersi

\begin{tabular}{|c|c|c|c|}
\hline Test & Estimate & df & Estimate/df \\
\hline Deviance & 76,532 & 72 & 1,063 \\
\hline Pearson Chi-Square & 102,124 & 72 & 1,418 \\
\hline
\end{tabular}

variabel respon mengalami kondisi overdispersi. Akibatnya, regresi Poisson tidak layak digunakan karena tidak memenuhi asumsi equidispersi.

\subsection{Model Regresi Zero-Inflated Poisson}

Berikut ini disajikan hasil estimasi parameter untuk model log link dan model logit regresi Zero-Inflated Poisson.

Tabel 8. Hasil estimasi parameter untuk model log link regresi ZIP

\begin{tabular}{|c|c|c|}
\hline Variabel & Parameter & Estimasi \\
\hline Intersep & $\beta_{0}$ & $-2,9818$ \\
\hline$X_{1}$ & $\beta_{1}$ & 0,2214 \\
\hline$X_{2}$ & $\beta_{2}$ & $-0,0034$ \\
\hline$X_{3}$ & $\beta_{3}$ & $-0,1015$ \\
\hline$X_{4}$ & $\beta_{4}$ & $-0,0110$ \\
\hline$X_{5}$ & $\beta_{5}$ & 0,0953 \\
\hline$X_{6}$ & $\beta_{6}$ & 0,0451 \\
\hline$X_{7}$ & $\beta_{7}$ & $-0,0055$ \\
\hline
\end{tabular}

Tabel 9. Hasil estimasi parameter untuk model logit regresi ZIP

\begin{tabular}{|c|c|c|}
\hline Variabel & Parameter & Estimasi \\
\hline Intersep & $\gamma_{0}$ & 44,9890 \\
\hline$X_{1}$ & $\gamma_{1}$ & 0,9832 \\
\hline$X_{2}$ & $\gamma_{2}$ & $-0,0611$ \\
\hline$X_{3}$ & $\gamma_{3}$ & $-0,4765$ \\
\hline$X_{4}$ & $\gamma_{4}$ & $-0,2123$ \\
\hline$X_{5}$ & $\gamma_{5}$ & $-0,1176$ \\
\hline$X_{6}$ & $\gamma_{6}$ & 0,2127 \\
\hline$X_{7}$ & $\gamma_{7}$ & $-0,0165$ \\
\hline
\end{tabular}

Pada Tabel 9 dapat dilihat bahwa terdapat tiga variabel prediktor yang berpengaruh signifikan terhadap variabel respon yaitu variabel $X_{1}, X_{3}$, dan $X_{6}$ karena variabel tersebut memiliki nilai $p$-value yang lebih kecil dari $\alpha$ sebesar 0,05. Dengan demikian, diperoleh tiga variabel prediktor yang berpengaruh dalam model dan variabel lainnya dapat dikeluarkan dari model. Berikut hasil analisis regresi ZIP dengan variabel yang signifikan. 
Tabel 10. Hasil analisis regresi Zero-Inflated Poisson dengan variabel yang terpilih

\begin{tabular}{|c|c|c|c|c|c|}
\hline Variabel & Parameter & Estimasi & $\exp (\beta)$ & $\mathbf{S E}$ & $\boldsymbol{p}$-value \\
\hline Intersep & $\beta_{0}$ & 7,61179 & 2021,8941 & 3,30534 & 0,02129 \\
\hline$X_{1}$ & $\beta_{1}$ & 0,14901 & 1,1607 & 0,06036 & 0,01356 \\
\hline$X_{3}$ & $\beta_{3}$ & $-0,11494$ & 0,8914 & 0,03530 & 0,00113 \\
\hline$X_{6}$ & $\beta_{6}$ & 0,03793 & 1,0387 & 0,01720 & 0,02738 \\
\hline Intersep & $\gamma_{0}$ & 12,11165 & 181979,6233 & 6,55840 & 0,0648 \\
\hline$X_{1}$ & $\gamma_{1}$ & 0,02623 & 1,0266 & 0,13721 & 0,8484 \\
\hline$X_{3}$ & $\gamma_{3}$ & $-0,14697$ & 0,8633 & 0,08337 & 0,0779 \\
\hline$X_{6}$ & $\gamma_{6}$ & 0,02386 & 1,0242 & 0,04128 & 0,5633 \\
\hline
\end{tabular}

Selanjutnya, akan dilakukan uji signifikansi parameter model regresi ZeroInflated Poisson menggunakan statistik uji Wald dengan kriteria uji tolak $H_{0}$ jika $W_{j}>\chi_{\alpha(1)}^{2}$. Pada pengujian ini digunakan taraf signifikansi $\alpha=5 \%$ sehingga diperoleh nilai $\chi_{\alpha(1)}^{2}=\chi_{0,05(1)}^{2}=3,841$. Hasil pengujian signifikansi parameter untuk regresi ZIP diperoleh sebagai berikut.

Tabel 11. Hasil Pengujian Signifikansi Parameter regresi Zero-Inflated Poisson

\begin{tabular}{|c|c|c|c|}
\hline Parameter & $W_{j}$ & $\chi_{0,05(1)}^{2}$ & Keterangan \\
\hline$\beta_{1}$ & 6,09442 & 3,841 & Tolak $H_{0}$ \\
\hline$\beta_{3}$ & 10,60213 & 3,841 & Tolak $H_{0}$ \\
\hline$\beta_{6}$ & 4,86305 & 3,841 & Tolak $H_{0}$ \\
\hline$\gamma_{1}$ & 0,03655 & 3,841 & Tidak Tolak $H_{0}$ \\
\hline$\gamma_{3}$ & 3,22292 & 3,841 & Tidak Tolak $H_{0}$ \\
\hline$\gamma_{6}$ & 0,33409 & 3,841 & Tidak Tolak $H_{0}$ \\
\hline
\end{tabular}

Dari hasil pengujian signifikansi parameter, untuk model log link diperoleh bahwa parameter $\beta_{1}, \beta_{3}$ dan $\beta_{6}$ signifikan pada tingkat signifikansi $5 \%$. Jadi, terdapat pengaruh dari persentase BBLR, persentase kunjungan neonatal selama $3 \mathrm{x}$ dan persentase bayi yang diberikan ASI eksklusif terhadap besarnya nilai harapan $\left(\mu_{i}\right)$ kematian bayi di Kota Bandung Tahun 2019. Untuk model logit diperoleh bahwa parameter $\gamma_{1}, \gamma_{3}$ dan $\gamma_{6}$ tidak signifikan pada tingkat signifikansi $5 \%$.

\subsection{Pengujian overdispersi pada model regresi Zero-Inflated Poisson}

Selanjutnya dilakukan kembali pengujian overdispersi pada model regresi ZeroInflated Poisson dan diperoleh hasil yang dapat dilihat pada Tabel 12 berikut.

Berdasarkan Tabel 12 diperoleh nilai Pearson Chi-Square yang dibagi derajat bebas sebesar 0,9875 dimana nilai tersebut kurang dari 1. Akibatnya, variabel respon tidak mengalami kondisi overdispersi dan regresi Zero-Inflated Poisson layak digunakan karena sudah memenuhi asumsi equidispersi. 
Tabel 12. Uji Overdispersi

\begin{tabular}{|c|c|c|c|}
\hline Test & Estimate & df & Estimate/df \\
\hline Pearson Chi-Square & 73,0720 & 74 & 0,9875 \\
\hline
\end{tabular}

\subsection{Interpretasi Model}

Berdasarkan pengujian signifikansi parameter, maka diperoleh model untuk regresi Zero-Inflated Poisson sebagai berikut :

$$
\begin{array}{r}
\ln \left(\mu_{i}\right)=\left(7,61179+0,14901 X_{1 i}-0,11494 X_{3 i}+0,03793 X_{6 i}\right) \\
\operatorname{logit}\left(\omega_{i}\right)=\left(12,11165+0,02623 X_{1 i}-0,14697 X_{3 i}+0,02386 X_{6 i}\right)
\end{array}
$$

Untuk model logit, variabel prediktor $X_{1}, X_{3}$, dan $X_{6}$ tidak signifikan terhadap variabel respon pada tingkat signifikansi $\alpha=0,05$, sehingga hanya model log link yang akan diinterpretasikan dimana persentase berat badan bayi lahir rendah $(\mathrm{BBLR})\left(X_{1}\right)$, persentase kunjungan neonatal selama $3 \times\left(X_{3}\right)$ dan persentase bayi yang diberikan ASI eksklusif $\left(X_{6}\right)$ signifikan di dalam model.

Model log link dari regresi Zero-Inflated Poisson menjelaskan bahwa setiap peningkatan $1 \%$ berat badan bayi lahir rendah akan menaikkan ln rata-rata kematian bayi di Kota Bandung Tahun 2019 sebesar 0,14901 dengan asumsi faktor lain tetap. Setiap peningkatan $1 \%$ kunjungan neonatal selama $3 \times$ akan menurunkan In rata-rata kematian bayi di Kota Bandung Tahun 2019 sebesar 0,11494 dengan asumsi faktor lain tetap. Setiap peningkatan $1 \%$ bayi yang mendapat ASI eksKlusif akan menaikkan ln rata-rata kematian bayi di Kota Bandung Tahun 2019 sebesar 0,03793 dengan asumsi faktor lain tetap.

\section{Kesimpulan}

Dari hasil analisis model regresi Zero-Inflated Poisson diperoleh model untuk kasus jumlah kematian bayi di Kota Bandung Tahun 2019 yaitu:

$$
\begin{array}{r}
\ln \left(\mu_{i}\right)=\left(7,61179+0,14901 X_{1 i}-0,11494 X_{3 i}+0,03793 X_{6 i}\right) \\
\operatorname{logit}\left(\omega_{i}\right)=\left(12,11165+0,02623 X_{1 i}-0,14697 X_{3 i}+0,02386 X_{6 i}\right)
\end{array}
$$

Model logit regresi Zero-Inflated Poisson menjelaskan bahwa peluang jumlah kematian bayi bernilai nol di Kota Bandung tidak dipengaruhi oleh persentase berat badan bayi lahir rendah, persentase kunjungan neonatal selama $3 \times$, dan persentase bayi yang diberikan ASI eksklusif, karena variabel prediktor tersebut tidak signifikan terhadap variabel respon pada taraf signifikansi $\alpha=0,05$.

Model log link regresi Zero-Inflated Poisson menjelaskan bahwa jumlah kematian bayi akan bertambah jika persentase bayi dengan berat badan lahir rendah di Kota Bandung mengalami peningkatan, kondisi ini sesuai dengan dugaan umum karena jika bayi dengan berat badan lahir rendah persentasenya meningkat, maka bisa menyebabkan kematian pada bayi. Jumlah kematian bayi di Kota Bandung akan bertambah jika persentase kunjungan neonatal selama $3 \times$ mengalami penurunan, kondisi ini sesuai dengan dugaan umum karena jika bayi yang memperoleh 
pelayanan kunjungan neonatal selama $3 \times$ persentasenya menurun, maka jumlah kematian bayi bisa meningkat. Oleh karena itu, kunjungan neonatal pada bayi sangatlah penting karena bayi memerlukan pelayanan komprehensif sesuai standar pada kunjungan bayi baru lahir sehingga kesehatan bayi lebih terjaga. Sebaliknya, jumlah kematian bayi di Kota Bandung akan bertambah jika persentase bayi yang diberikan ASI ekslusif mengalami peningkatan, kondisi ini tidak sesuai dengan dugaan umum, hal ini disebabkan karena sesuai dengan analisis sebelumnya karena jika di Kota Bandung persentase bayi dengan berat badan lahir rendah meningkat maka bisa menyebabkan kematian pada bayi sehingga walaupun bayi yang diberikan ASI ekslusif meningkat tidak akan menambah jumlah kematian bayi.

Selanjutnya, diperoleh bahwa faktor-faktor yang berpengaruh secara signifikan pada kasus jumlah kematian bayi di Kota Bandung yaitu persentase berat badan bayi lahir rendah $\left(X_{1}\right)$, persentase kunjungan neonatal selama $3 \mathrm{x}\left(X_{3}\right)$ dan persentase bayi yang diberikan ASI eksklusif $\left(X_{6}\right)$.

\section{Daftar Pustaka}

[1] Bain, L.J and Max E. 1991. Introduction to Probability and Mathematical Statistics. Second Edition. Duxbury Press, California

[2] Chaniago, P.R, Devianto, D., dan Rahmi, I.H.G., 2018. Analisis Pemodelan Faktor Risiko Angka Kematian Ibu dengan Pendekatan Regresi Poisson. Jurnal Matematika UNAND. 7(2): $126-131$

[3] Dewanti, N.P.P, Made S, dan I G.A.M.S. 2016. Perbandingan Regresi Zero Inflated Poisson (ZIP) dan Regresi Zero Inflated Negative Binomial (ZINB) pada Data Overdispersion (Studi Kasus: Angka Kematian Ibu di Provinsi Bali). E-Jurnal Matematika. 5(4): 133 - 138

[4] Dinas Kesehatan Kota Bandung. "Profil Kesehatan Kota Bandung Tahun 2019".

[5] Nur, I.M. 2018. Pemodelan Infant Mortality Rate (IMR) dengan Pendekatan Zero Inflated Poisson Regression Berbasis Algoritma EM. Jurnal Statistika Industri dan Komputasi. 3(1): $71-78$

[6] Ramadhani, N, Yanuar, F., dan Yozza, H., 2018. Penerapan Regresi Poisson dan Generalized Poisson Regression dalam Memodelkan Angka Kematian Ibu di Sumatera Barat Tahun 2015. Jurnal Matematika UNAND. 7(2): 112 - 117

[7] Siregar, R.S.K. Pemodelan Regresi Zero Inflated Poisson (ZIP) dan Hurdle Model Pada Kasus Penyakit Tetanus Neonatorum. Jurnal Euclid. 6(2): 117 129

[8] Taufan, M, Agus R, dan Suparti. 2012. Analisis Faktor-Faktor yang Mempengaruhi Banyaknya Klaim Asuransi Kendaraan Bermotor Menggunakan Model Regresi Zero-Inflated Poisson (Studi Kasus di PT. Asuransi Sinar Mas Cabang Semarang Tahun 2010). Jurnal Media Statistika. 5(1): 49 - 61

[9] Zuhrat, L, Devianto, D., dan Rahmi, I.H.G., 2019. Pemodelan Jumlah Kasus DBD yang Meninggal di Kota Padang dengan Menggunakan Regresi Poisson. Jurnal Matematika UNAND. 4(4): $57-64$ 